\title{
Physiological maturity of fruits and seeds of Poincianella pyramidalis (Tul.) L.P. Queiroz ${ }^{1}$
}

\author{
Cosmo Rufino de Lima², Riselane de Lucena Alcântara Bruno ${ }^{2 *}$, Katiane da Rosa \\ Gomes da Silva ${ }^{2}$, Mauro Vasconcelos Pacheco ${ }^{3}$, Edna Ursulino Alves ${ }^{2}$, \\ Albericio Pereira de Andrade ${ }^{4}$
}

\begin{abstract}
The Leguminosae family is one of the most representative botanical families of the Caatinga, with 80 endemic species, highlighting the catingueira (Poincianella pyramidalis). The objective of this research work was to study the maturation process of $P$. pyramidalis seeds based on the physiological maturity. Five harvest of fruits and seeds were carried out, with 15 days interval each, in a period from July to September 2010. The harvests began 75 days after anthesis (d.a.a.) and lasted until 135 d.a.a. Fruits and seeds were subjected to the following assessments: size, moisture content, and dry mass of fruits and seeds; and germination and vigor of seeds (first count of germination, germination speed index, length and dry mass of seedling). Under the environmental conditions of municipality of Soledade, State of Paraiba, Northeast Brazil, the point of physiological maturity of $P$. pyramidalis seeds occurs at 125 d.a.a., when the maximum accumulation of dry mass is $1.993 \mathrm{~g}$ and moisture content is $21 \%$. The ideal point of harvest is between 130 d.a.a and 135 d.a.a., before natural dehiscence, when the moisture content of seeds is between $13.0 \%$ and $5.0 \%$.
\end{abstract}

Index terms: catingueira, semiarid, maturity, vigor, Caatinga.

\section{Maturação fisiológica de frutos e sementes de Poincianella pyramidalis (Tul.) L.P. Queiroz}

RESUMO - A família Leguminosae é uma das mais representativas famílias botânicas da Caatinga, com 80 espécies endêmicas, destacando-se a catingueira (Poincianella pyramidalis). O objetivo desta pesquisa foi estudar o processo de maturação de sementes de $P$. pyramidalis com base no ponto de maturidade fisiológica. Foram realizadas cinco colheitas de frutos e sementes, em intervalos quinzenais, no período de julho a setembro de 2010. As colheitas se iniciaram aos 75 dias após a antese (d.a.a.) e se estenderam até os 135 d.a.a.. Os frutos e as sementes foram submetidos às seguintes avaliações: tamanho, teor de umidade e massa seca de frutos e de sementes; e germinação e vigor das sementes (primeira contagem de germinação, índice de velocidade de germinação, comprimento e massa seca de plântulas). Nas condições do município de Soledade - PB, o ponto de maturidade fisiológica de sementes de P. pyramidalis, ocorre aos 125 d.a.a., quando o acúmulo máximo de massa seca é $1,993 \mathrm{~g}$ e o teor de umidade é $21 \%$. O ponto ideal de colheita é atingido entre 130 d.a.a. e 135 d.a.a., antes da deiscência natural, quando as sementes têm teor de umidade entre $13,0 \%$ e $5,0 \%$.

Termos para indexação: catingueira, semiárido, maturidade, vigor, Caatinga.

${ }^{1}$ Submitted on 06/29/2011. Accepted for publication on 11/30/2011.

${ }^{2}$ Departamento de Fitotecnia e Ciências Ambientais, UFPB, Caixa Postal 22, 58397-000 - Areia, PB, Brasil.

${ }^{3}$ Universidade Federal do Rio Grande do Norte, Caixa Postal 1524, 59078-970 - Natal, RN, Brasil.
${ }^{4}$ Departamento de Zootecnia, UFPB, 58397-000 - Areia, PB, Brasil.

*Corresponding author<lane@cca.ufpb.br> 


\section{Introduction}

Poincianella pyramidalis (Tul.) L.P. Queiroz is an arboreal species endemic to the Caatinga (Monteiro et al. 2005), popularly known by its common name "catingueira" (Braga, 1960), which is found in several plant associations occurring in the states of Piauí, Ceará, Rio Grande do Norte, Paraiba, Pernambuco, Alagoas, Sergipe, Bahia, and Northern Minas Gerais being widely used by local communities for production of firewood and charcoal (Silva et al. 2009).

Despite the large number of native species of Caatinga, little is known about the physiological maturity and ideal harvest point for their fruits and seeds with maximum quality and vigor, as well as the potential use of these seeds in relation to recuperation and conservation of ecosystems, aiming at providing subsidiary tools for the rural producers of that region.

One of the factors influencing quality of seeds is its maturation stage, since further detailed studies on such process provide additional information on behavior of the species, thus allowing for prediction and establishment of the most proper harvest point (Gemaque et al. 2002). When harvest is performed at unsuitable moment it leads to considerable seed quality losses, besides inducing quantitative losses. Therefore, the maturation process and its relationships with the proper harvest point need to be perfectly known (Marcos-Filho, 2005). The author also stresses that, for the majority of plant species, the ideal harvest point depends on the physiological maturity of seeds, which is the moment in which the transference of dry matter from plant to the seeds ceases.

Several research works have been carried out aiming at harvesting seeds of forest species with the maximum physiological quality. For example: the use of dry mass as an indicator of maturation was efficient for determining the physiological maturity of seeds of Tibouchina granulosa (Lopes et al. 2005), Mucuna aterrima (Piper et Tracy) Holland (Nakagawa et al. 2005), and Mimosa caesalpiniifolia Benth. (Alves et al. 2005). Studies with Piptadenia viridiflora (Kunth) Benth, however, have proved that the moisture content together with maximum accumulation of dry mass, assessed during the germination test, were essential for defining the germination capacity of seeds (Pessoa et al. 2010).

Therefore, the objective of this research work was to study the maturation process of seeds of Poincianella pyramidalis by characterizing their physiological maturity as well as to establish their ideal harvest point.

\section{Material and Methods}

The field study was carried out at "Açude" farm, in the municipality of "Soledade", State of Paraiba, within the micro-region of western "Curimataú" in the Paraiban "Agreste" (7 7' 22" S; 36 19' 33" W), located at $10 \mathrm{~km}$ from the BR-230 road, Northeast Brazil. The area has a predominantly soft-wavy relief, with altitude of $535 \mathrm{~m}$. According to the classification of Köppen, the climate within the region is predominantly hot and dry, of the semiarid type and $\mathrm{BS}$ 'h subtype, with average annual precipitation of $500 \mathrm{~mm}$, maximum temperature of $31^{\circ} \mathrm{C}$ and minimum temperature of $16.7^{\circ} \mathrm{C}$, with slight variations, and relative humidity around $65 \%$.

Characterization of individual plants and marking of inflorescences: 26 vigorous plants, with an average height ranging from $1.50 \mathrm{~m}$ to $4.00 \mathrm{~m}$ and a suitable phytosanitary external aspect were selected. After detecting plants with flowers in full anthesis (more than 50\%), the marking of inflorescences was performed in all the plant canopy using wool yarns.

Harvest of fruits and seed: from the beginning of fruit formation (first week after anthesis) their development was monitored by biometric measurements in the field. After detecting formation of seeds, five manual harvests, with 15 days interval each, were carried out from 75 days after anthesis (d.a.a.) until the $135^{\text {th }}$ d.a.a. After harvesting, the fruit samples were immediately placed into thermic containers and brought to the Seed Analysis Laboratory of the Agrarian Sciences Center of the Federal University of Paraiba for assessment of physiological quality.

Biometric characterization of fruits and seeds: from the $15^{\text {th }}$ d.a.a. until the $60^{\text {th }}$ d.a.a. the length, width, and thickness of fruits were measured in the field with the aid of digital spring caliper, without removing the fruits from the plants; and from the $75^{\text {th }}$ d.a.a. until the $135^{\text {th }}$ d.a.a. the assessments of fruits and seeds were performed under laboratory conditions.

Color of fruits and seeds: to determine color of fruits and seeds along their development until full maturity, they were visually sorted into different maturation stages: stage I (light-green color) fruits presenting entirely a light-green color; stage II (reddish color) fruits with green color, but with reddish hues; stage III (greenish color) fruits with a entirely dark-green color; and stage IV (brownish color) pods with a entirely brown color.

Moisture content and dry mass of fruits and seeds (\%): were determined by the oven at $105 \pm 3{ }^{\circ} \mathrm{C}$, for $24 \mathrm{~h}$ (Brasil, 
2009). Four samples of two fruits each, and 20 seeds for each harvest time were used.

Germination test: preliminary tests were performed for defining the most adequate conditions for the procedures of the germination test. For each harvest time, seeds were subjected to germination test, which was carried out into $11 \mathrm{~cm} \times 11 \mathrm{~cm}$ x $3 \mathrm{~cm}$ transparent acrylic germination boxes (Gerbox), with four replications of 25 seeds each, evenly distributed within a previously autoclaved sand substrate moistened with sterile distilled $\mathrm{H}_{2} \mathrm{O}$, and with a water retention capacity of $60 \%$. The gerbox were then placed into a BOD type germinator, under alternating temperatures of $20^{\circ} \mathrm{C}$ and $30^{\circ} \mathrm{C}$, and $8 / 16 \mathrm{~h}(\mathrm{~L} / \mathrm{D})$ photoperiod. The number of germinated seeds was daily assessed until the $13^{\text {th }}$ day after sowing, considering only the normal seedlings, according to Brasil (2009) and adopting as germination criterion the emergence of cotyledons and the springing of the hypocotyl.

First count of germination: it was used the same procedure utilized in the test of germination, performing the assessment in the $6^{\text {th }}$ day after starting the test in the moment in which the majority of seedlings, in all treatments (substrate $\mathrm{x}$ temperature), had emerged.

Emergence speed index (ESI): it was carried out together with the test of germination, by using the assessments daily performed for the germinated seeds test, and by computing the ESI according to the methodologies and equation proposed by (Maguire, 1962).

Seedling length: at the end of the germination test, the normal seedlings were measured from root until insertion of first leaf with the aid of a ruler graduate in centimeters. Results were expressed in $\mathrm{cm}$. seddling ${ }^{-1}$.
Dry mass of seedlings: after measurement, the seedlings were packaged into Kraft type paper bags and then placed into an air forced circulation oven at $65{ }^{\circ} \mathrm{C}$ until reaching constant weight. Immediately after, the samples were removed from the oven, placed into desiccators and then weighted in a $0.001 \mathrm{~g}$ precision analytical balance. Results were expressed in mg. seedling-1 (Alves et al. 2006).

Statistical procedures: the experiments were carried out using a completely randomized experimental design (CRD). For each variable, data non-transformed were subjected to ANOVA and to Polynomial Regression Analysis (program WinStat software, version 1.0, Federal University of Pelotas) in function of harvest times. The linear, quadratic, and cubic models were tested, and afterwards the most significant model of highest order that could explain the results expressing estimates of possible occurrences was selected.

\section{Results and Discussion}

In relation to maturation index, based on the color of fruits (Figure 1), it can be verified that since the beginning of development (5 d.a.a.) these had the typical color of stage I (light-green), which was maintained until circa 30 d.a.a. Starting from 45 d.a.a. the hue was altering until reaching the color of stage II (reddish) and keeping that color hue until 60 d.a.a. Due to evolutions of maturation of fruits internal tissues, probably the reddish tone may be associated to chlorophyll degradation and synthesis of preexisting pigments responsible for that characteristic color of fruits of each plant species.

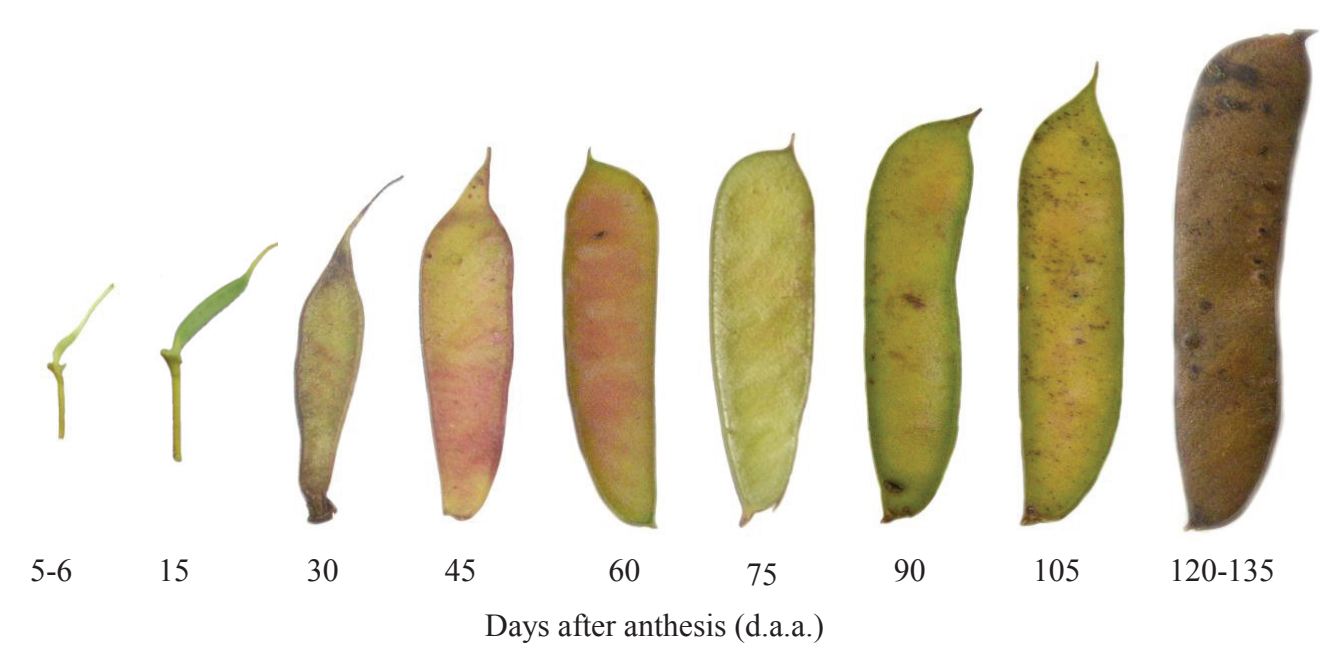

Figure 1. Color of P. pyramidalis fruits from the beginning of their formation (5 to 6 d.a.a.) until the end of the final maturation phase (between 120 d.a.a. and 135 d.a.a.). 
With the gradual development of the maturation process (Figure 1), approximately at 75 d.a.a. the color again changed to that of stage I (light-green) beginning to acquire then a darker and shiny hue with little spots of brown color, thus passing from stage I to the stage III (darker green). In studies on seed maturation of Mucuna aterrima, Nakagawa et al. (2007) also found that pods maintained a light-green color, with slight alterations of hues, until the fourth harvest (56 days after flowering) and then passed to the red color with brown dots.

Afterwards, the fruits of $P$. pyramidalis became drier, acquiring darker hues with a leathery aspect, reaching the stage IV (light-brown) from 120 d.a.a. until 135 d.a.a. It was also observed that after 135 d.a.a., there was not condition for performing a new harvest, due to the natural dehiscence of the fruits through a longitudinal aperture, from where the seeds were dispersed.

In this sense, the light brown color of fruits can be considered as an important indicator for determining seed physiological maturity, once in this moment the fruits still did not initiate the natural dehiscence. Such premise has been already considered by Nakagawa et al. (2005) in observing that the species Mucuna aterrima likewise presents alterations on color of pods and seeds, also being important indicators for the determination of physiological maturity for that species.

In relation to $P$. pyramidalis seeds (Figure 2) it is verifiable that they likewise passed by a continuous and marked process of changes in the color since the beginning of their formation. At 30 d.a.a. the light-green color seeds passed to a darker green hue, remaining with that color until 90 d.a.a. After this time span the seeds again began changing color, reaching at 105 d.a.a., a bright light brown color. At 120 d.a.a. the seed adquired an opaque light-brown color (not shiny), but with reduced size due to loss of water (29\%) during the maturation process (Figure $3 \mathrm{D}$ ); and at 135 d.a.a. they had a dark brown hue, probably related to their desiccation.

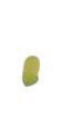

30

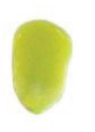

45

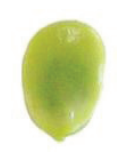

$60-75$

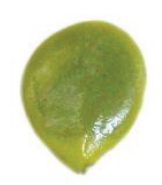

90

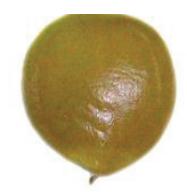

105

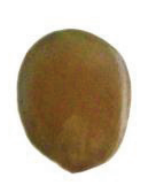

120

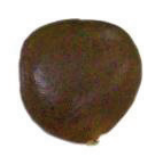

135

Days after anthesis

Figure 2. Color of P. pyramidalis seeds from the beginning of their formation (30 d.a.a.) until the harvest final point (135 d.a.a.).

For the size of fruits of P. pyramidalis (Figure 3A) an increasing behavior was observed, mainly for the length variable. By analyzing data, however, it is possible to verify that the largest length of fruits in relation to maturity periods occurred at 110 d.a.a. $(81.98 \mathrm{~mm})$, a moment in which they started changing from the color of stage III (darker green) to stage IV (light brown) (Figure 1) visually displaying the evolution of their maturation. Alves et al. (2005) observed that, during the physiological maturation, the seeds of Mimosa caesalpiniifolia gradually increased in length and width along the maturation process, reaching the maximum estimated values of $106.08 \mathrm{~mm}$ and $12.32 \mathrm{~mm}$, respectively, at the $129^{\text {th }}$ d.a.a. and $136^{\text {th }}$ d.a.a.

In this research work it was found that for the width of fruits (Figure 3A) the highest values were obtained when fruits were at 120 d.a.a. $(20.15 \mathrm{~mm})$ and, starting from that point, occurred a reduction of this variable at 135 d.a.a., reaching average values of $17.94 \mathrm{~mm}$. The reduction on width of fruits may be related to their desiccation, due to low moisture content (Figure 3C). For the thickness data it was noticed that they were $1.01 \mathrm{~mm}$ thick at the beginning of the assessment (15 d.a.a.) and only reached the maximum values at 135 d.a.a. $(4.27 \mathrm{~mm})$. During the period in which the fruits presented the largest dimensions, their moisture content was above $25 \%$.

The biometry of fruits and seeds are important subsides for the differentiation of species within a genus and among varieties within the same species (Cruz et al., 2001; Alves et al., 2007), as the case of Hymenaea stigonocarpa Mart. ex Hayne, H. courbaril L., and $H$. intermedia Ducke. It can also constitute an adaptive response to the environment (De-Carvalho et al., 2005). 

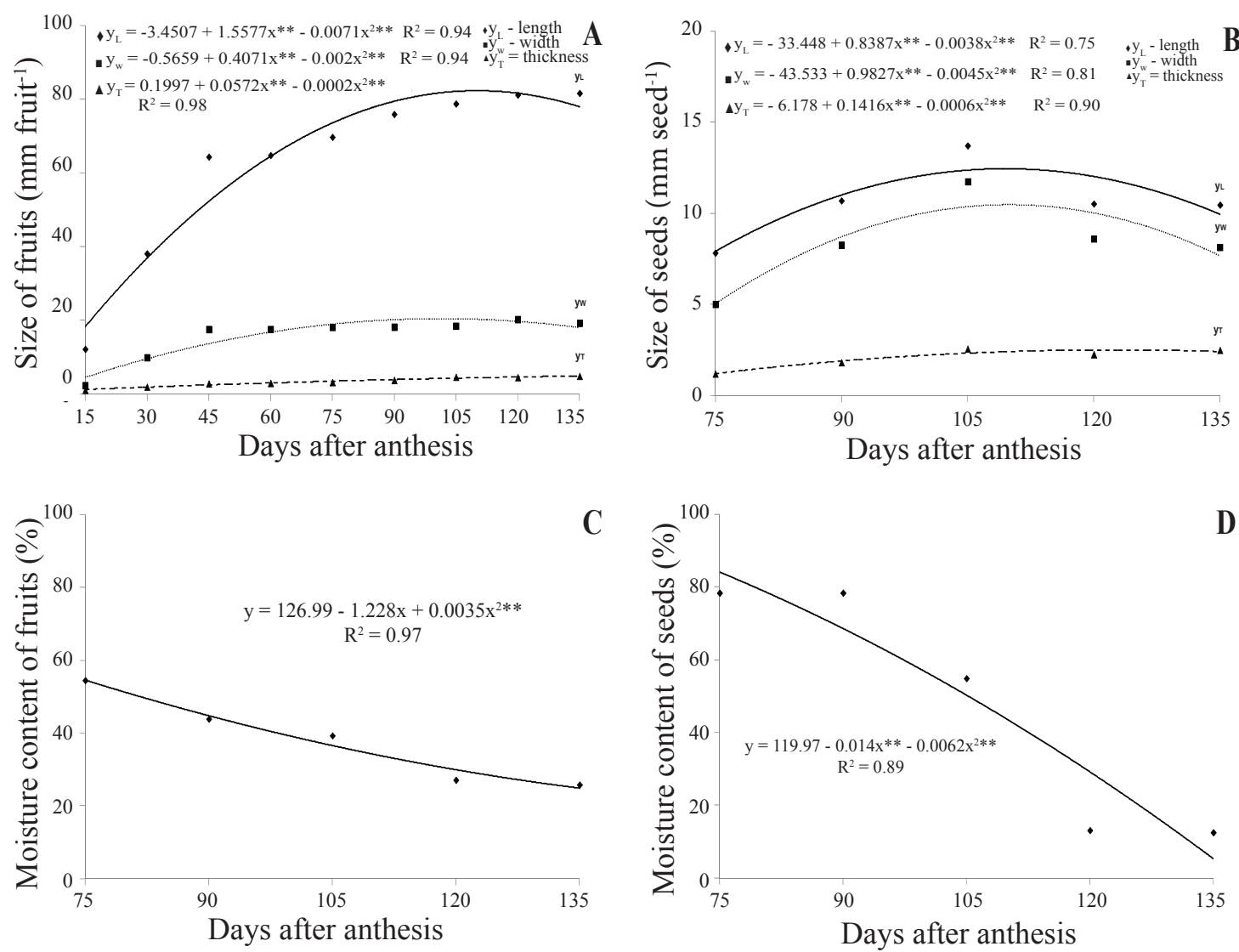

Figure 3. Length, width, and thickness of fruits (A) and seeds (B); moisture content of fruits (C) and seeds (D) of $P$. pyramidalis harvested in different periods (Days after anthesis).

The size of fruits in Cnidosculus quercifolius Pax \& K. Hoffm. gradually increased, reaching maximum values in 58 days after flowering. At this point, results on percentage and speed of germination as well as on dry mass of fruits and seeds were lower than those obtained at 65 and 72 days after flowering, respectively (Silva et al., 2008). According to the same authors, the size of fruits is not an efficient variable for physiological maturity determination.

According to results shown on Figure $3 \mathrm{~B}$, it can be noticed that similarly to what was observed for fruit dimensions, the data on length of seeds have also shown their continuous increase until 110 d.a.a. (12.80 mm). In the moment in which seeds reached their maximum length, their moisture content was still very high, circa $43.4 \%$ (Figure 3D) and these had a clear and shiny brown color (Figure 2) due to their high moisture content. The fact of seeds reaching rapidly their maximum size can probably be attributed to their need in maintaining an elevated moisture content until a given period of photosynthates accumulation.

Concerning data on seed width (Figure $3 \mathrm{~B}$ ), they also fit the quadratic model, with increments of $4.85 \mathrm{~mm}$ since the first harvest (75 d.a.a.) until reaching their maximum values at 109 d.a.a. $(10.11 \mathrm{~mm})$. Starting from this point, a slight reduction $(7.12 \mathrm{~mm})$ occurred until 135 d.a.a. Such reduction in seed size may be probably due to their desiccation during maturation when they reach their maximum desiccation level (Figure 3D). It was likewise detected an increase in the seed thickness, and the maximum value for this variable was found at 118 d.a.a. $(2.17 \mathrm{~mm})$ reaching $2.0 \mathrm{~mm}$ at the end of the maturation process.

At 75 d.a.a. (Figure 3C) the moisture content of fruits was high $(54.5 \%)$. These values, however, have had significant reductions, reaching $24.9 \%$ moisture content in the moment in which the fruits were close to enter the dehiscence phase (135 d.a.a.). For the seeds, it was verified that likewise the moisture content was high (84\%) at the first harvest ( 75 d.a.a.) (Figure 3D) and from this point on occurred a sharp drop on moisture content, reaching values of $5 \%$ at 135 d.a.a. The elevated initial moisture content of seeds in the first harvest and its subsequent drop may be related to the importance of water in the conveying process of photosynthates (proteins, sugars, lipids, and other 
substances) which are accumulated during the seed maturation process. The water plays an important role on formation and maturation of seeds, with reduction of its content during all process, although remaining sufficiently elevated to allow for the transference of the dry mass from plants to seeds. While the seeds are in process of photosynthates accumulation, the dehydration is slow; but otherwise becomes accelerated when they reach the maximum dry mass. The dehydration level can actually define the seeds behavior as far as germination is concerned (Marcos-Filho, 2005).

The moisture content exerts accentuated influence on physical and chemical properties of arboreal species seeds and this determination is very important in all steps of the seed technology process (Carvalho, 2005). In assessing physiological quality on seeds of Tabebuia chrysotricha (Mart. Ex DC.), Fonseca et al., (2005) verified a rather high drop in the seed moisture contents, from $86.2 \%$ in the sixth week to $25.4 \%$ in the ninth week. Such decrease on moisture content was favored by the drying of fruits followed by their dehiscence, and can be an indicator of seed maturation.

For seeds of Mimosa caesalpiniifolia Alves et al., (2005) determined a moisture content level of $82.1 \%$ at 119 d.a.a. with a slow reduction until 147 d.a.a. From that date an accentuated drop in these figures occurred. Such variation on moisture content was also observed in seeds of Mucuna aterrima (Nakagawa et al., 2005) and Citharexylum montevidense (Spreng.) Moldenke (Leonhardt et al., 2001).

By examining data on results of dry mass accumulation in the fruits (Figure 4A) it can be seen that in the first harvest ( 75 d.a.a.) the amount of dry mass amassed in fruits was $2.251 \mathrm{~g}$ and the moisture content was high $(54.5 \%)$ (Figure 3C). From that point on, however, the values of dry mass were progressively increased, reaching maximum accumulation at 135 d.a.a. $(2.746 \mathrm{~g})$ the moment in which the moisture content was significantly reduced to $24.9 \%$.
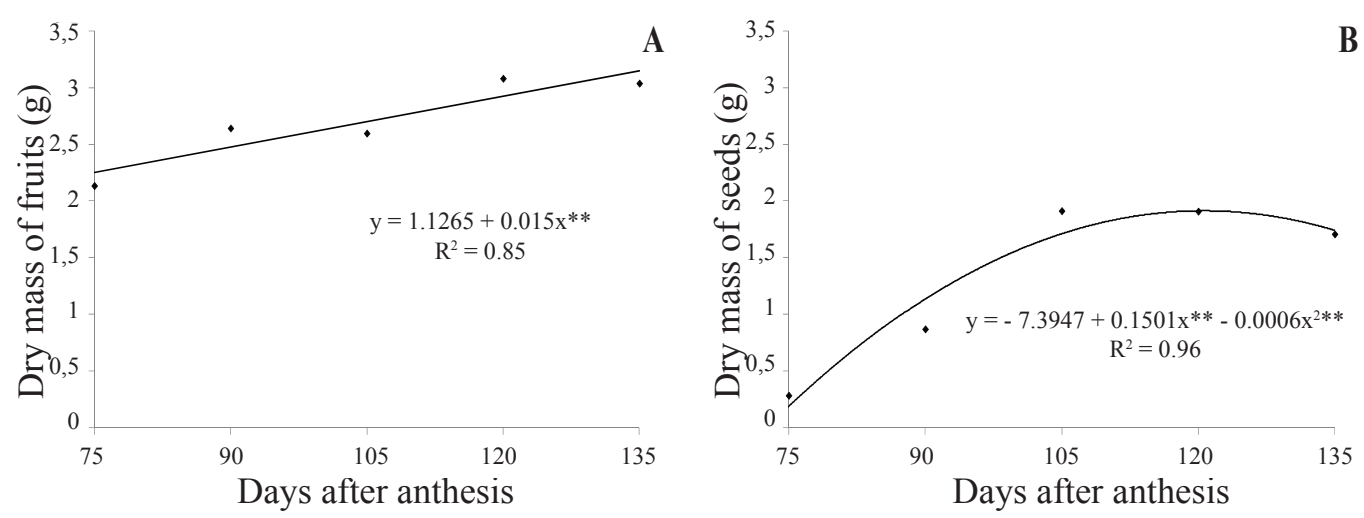

Figure 4. Dry mass of fruits (A) and seeds (B) of P. pyramidalis harvested in different periods (Days after anthesis).

In considering that water is responsible for the translocation of photosynthates from plant to the seed, it can be noticed that dry mass of seeds had a steady increase until 125 d.a.a., displaying their maximum accumulation of $1.993 \mathrm{~g}$ at this point (Figure 4B). This moment coincides with the period of highest reduction on seed moisture content (21\%), as illustrated on Figure 3D, and was considered as a possible indicator of seed physiological maturity occurrence. Such behavior was similar to that described by Carvalho and Nakagawa (2000) who reported that, during physiological maturation, the dry mass accumulation in the seed is initially slow. But soon after, a fast and constant accumulation phase starts and proceeds until a maximum level is reached and maintained for a certain period of time. At the end of this phase, however, the dry mass accumulation slightly decreases in consequence of losses due to the respiration process. The same authors recommend performing the harvest in the maximum point of dry mass accumulation in the seeds to avoid losses induced by environmental field adversities, which can possibly lead to seed deterioration.

Borges et al., (2005) found similar results in studies on increment of dry mass in seeds of Caesalpinia echinata from 32 d.a.a. to 70 d.a.a., and reported a maximum average value of $316 \mathrm{mg}^{-s^{2}} \mathrm{~d}^{-1}$, indicating that the physiological maturity of those seeds would probably be close from 60 d.a.a. to 65 d.a.a.

It can likewise be observed on Figure 4B that from 125 d.a.a. a significant reduction on dry mass of seeds started to occur. Probably the physiological disconnection of seeds from the mother-plant occurred during this phase, thus 
ceasing the nutrients translocation from plant to seed; and so the seeds only remained physically attached to the motherplant. In this moment, the color of fruits as well as the seeds acquired a light-brown hue (Figures 1 and 2, respectively).

This is the reason why the literature reports that the color of fruits and seeds can be considered as an auxiliary indicator in the determination of seed physiological maturity points and harvesting stage (Corvello et al. 1999). These same authors have found that such evidences are observed during the maturation process, when visible changes of external aspect and on the color occur, thus allowing for the characterization of maturity for seeds of Cedrela fissilis Vell. in which, starting from 32 weeks after anthesis, the fruits were presenting a dark brown color and beginning of dehiscence.

Contradictory results were found for seeds of Cnidosculus quercifolius in which the color of seeds is not an efficient indicator in determining physiological maturity, once variations along the maturation process occur. For the seeds of this species, a white coloration of the tegument was observed in the three first harvests, passing then to the brown color in the three subsequent harvests and returning to present a whitish coloration at 72 days after flowering (Silva et al. 2008).

As related to germination of $P$. pyramidalis seeds (Figure 5A) the percentage of germination increased gradually, reaching the maximum values of $74 \%$ at 125 d.a.a. and coinciding with the period in which dehydration of seeds intensified (Figure 3D) and occurred the maximum accumulation of dry mass (Figure 4B) and therefore becoming a probably suitable indicator of physiological maturity. Although the maximum germination percentage (77\%), however, only occurred at 135 d.a.a., i.e., 10 days after the maximum accumulation of dry mass.
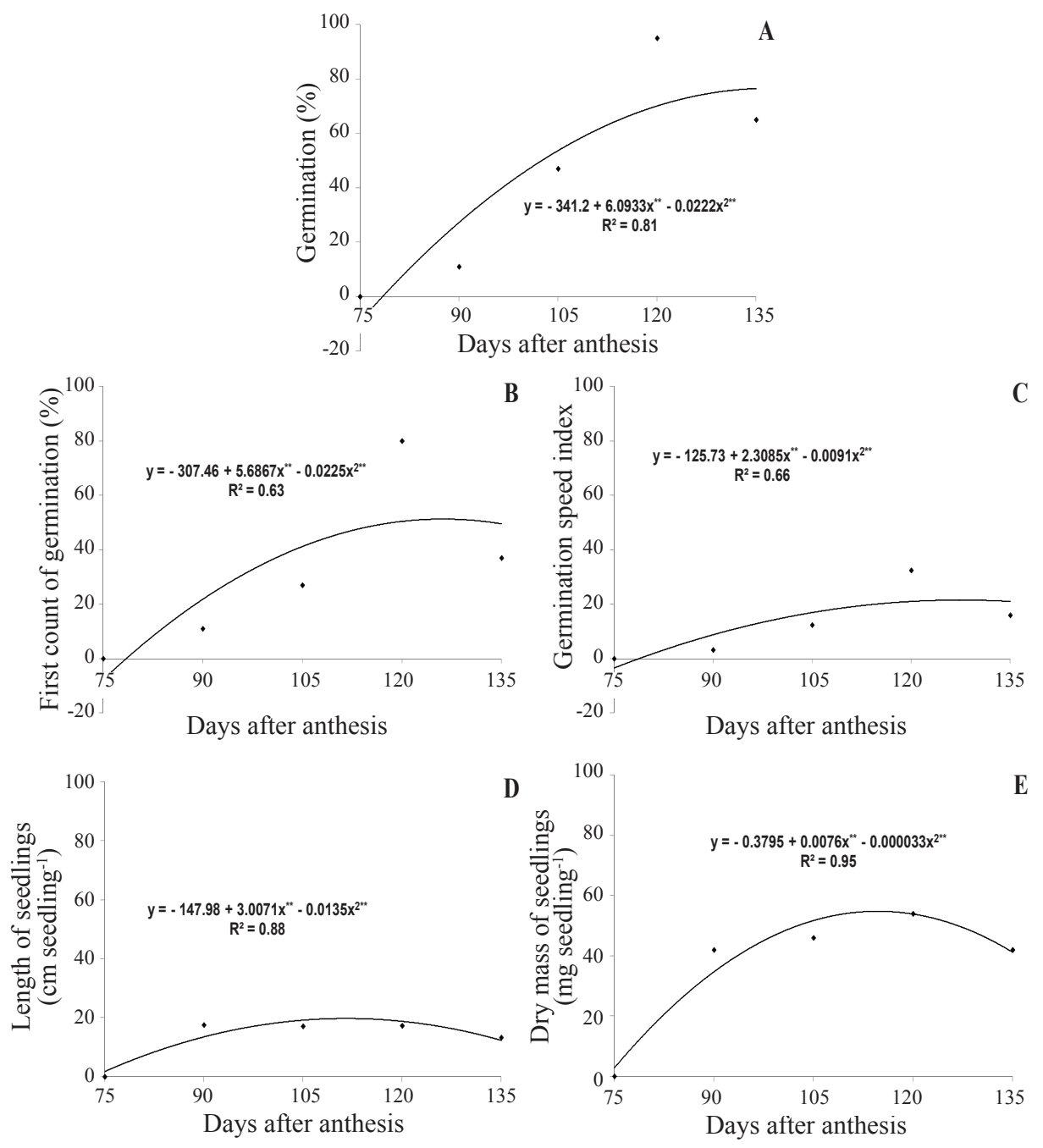

Figure 5. Percent germination (A), germination at first count (B), germination speed index (C), length of seedlings (D), and dry mass of seedlings (E) of $P$. pyramidalis harvested in different periods (Days after anthesis). 
In studies with Miconia cinnamomifolia (DC.) Naud, Lopes and Soares (2006) verified that the highest values for dry mass and that the lowest moisture content coincided with the maximum seed germination and length of hypocotyl, and occurred at 110 d.a.a. According to Iossi et al., (2007) the coincidence on the maximum values of dry mass and percentage of germination is common for the majority of plant species, thus establishing a correlation between these two studied variables for determining the seed physiological maturity point.

It is known that the seed maximum quality varies according to the plant species. For example: the maximum germination for seeds of Phoenix roebelenii occurred at 138 d.a.a. (Iossi et al., 2007); for seeds of Mucuna aterrima the maximum quality occurred at 91 days after flowering (Nakagawa et al., 2007); and for seeds of Tabebuia serratifolia Vahl Nich. the maximum germination was reached at 53 d.a.a. (Carvalho et al. 2008).

According to data referring to first count of germination obtained with seed from the first harvesting (Figure 5B), it is possible to verify that the seeds did not produce seedlings, probably due to their physiological immaturity, thus preventing the triggering of the germination process. The maximum value of that variable $(52 \%)$, however, was reached at 126 d.a.a. In relation to their vigor, evaluated by the germination speed index test, the values are presented on Figure $5 \mathrm{C}$, where it is noticeable that the maximum index (21) was obtained when seeds were harvested at 126 d.a.a. These values have a trend similar to those of dry mass (Figure 4B), percentage of germination (Figure $5 \mathrm{~A}$ ), and first count of germination (Figure 5B), therefore suggesting that the seeds harvested at that moment had already reached the physiological maturity and maximum quality. Concerning seedling length (Figure 5D), it was found that the highest value $(19.40 \mathrm{~cm})$ was only obtained with seedling of $P$. pyramidalis originated from seeds harvested at 111 d.a.a. Data referring to seed vigor, which was determinate by dry mass of seedlings (Figure 5E) have shown that the most vigorous seedlings were obtained with the seeds harvested at 115 d.a.a., i.e., with higher dry mass content (55 mg. seedling ${ }^{-1}$ ).

For seeds of Mimosa caesalpiniifolia, Alves et al. (2005) found satisfactory results by verifying maximum values for first count of germination (98\%) at 183 d.a.a. and by observing that, starting from this period, gradual and abrupt reductions on these percents occurred. In relation to length of seedlings, Dan et al. (1987) stated that if a higher incorporation of nutrients by the embryonic axis and, in addition, if higher capacity of transformation occurs for those nutrients, there will be a very high rate of seedlings growth and, consequently, the seeds that gave origin to those plants will be more vigorous. Similar fact was also verified by Alves et al. (2005) who working with seeds of Mimosa caesalpiniifolia found that those seeds reached maximum accumulation of dry mass $(0.008 \mathrm{~g})$ at 193 d.a.a.

According to results herein obtained, it can be seen that the maximum accumulation of dry mass of seeds occurred at 125 d.a.a. (Figure 4B), thus characterizing the point of physiological maturity coinciding with $74 \%$ germination (Figure 5A). At this same moment, however, the moisture content was circa $12.0 \%$ (Figure 3D). Notwithstanding, as the moisture content was still high, this would not be the adequate moment for determining the harvest point.

The harvest point is an activity resulting from a decision based on the analysis of technological and economical parameters (Marcos-Filho, 2005). Yet, according to the same author, the harvesting of seeds should not be recommended in the physiological maturity point, due to the high moisture content of seeds, since otherwise mechanical injuries might be induced by kneading. Hence, as the dehiscence of fruits occurs after 135 d.a.a., the period between 130 d.a.a. and 135 d.a.a. was chosen for determination of the harvest point, because during this period the highest reduction on moisture content of P. pyramidalis seeds occurred (between $13.0 \%$ and $5.0 \%$ ) (Figure 3D), therefore providing seeds with high percentage of germination (77\%) (Figure 5A).

After 135 d.a.a., the elevated water loss impairs the harvesting, once that culminates in the natural dehiscence of the fruit, which explosively releases the seeds in the environment due to contraction of cellular walls.

\section{Conclusions}

Under the environmental conditions of municipality of Soledade, State of Paraiba, the physiological maturity of seeds of Poincianella pyramidalis occurs at 125 days after anthesis;

The harvest point is reached at between 130 d.a.a. and 135 d.a.a., before the natural dehiscence, when seeds have low moisture content, i.e., between $13.0 \%$ and $5.0 \%$;

The maximum seed vigor, assessed by the first count of germination and germination speed index, coincide with maximum values of dry mass of seeds; and

The light brown color of fruits of $P$. pyramidalis fruits is a good visual indicator in the determination of the physiological maturity of seeds. 


\section{Acknowledgements}

To CNPq for the scholarship granted to researchers and graduate students in Agronomy of the "Centro de Ciências Agrárias da Paraíba", municipality of Areia, State of Paraiba (CCA/UFPB/Areia, PB).

\section{Referências}

ALVES, E.U.; BRUNO, R.L.A.; ALVES, A.U.; ALVES, A.U.; CARDOSO, E.A.; GALINDO, E.A.; BRAGA JUNIOR, J.M. Germinação e biometria de frutos e sementes de Bauhinia divaricata L. Sitientibus Série Ciências Biológicas, v.7, n.3, p.193-198, 2007. http:// www2.uefs.br/revistabiologia/pg7_n3.html

ALVES, E.U.; BRUNO, R.L.A.; OLIVEIRA, A.P.; ALVES, A.U.; ALVES, A.U. Ácido sulfúrico na superação da dormência de unidades de dispersão de juazeiro (Zizyphus joazeiro Mart.). Revista Árvore, v.30, n.2, p.187-195, 2006. http://www.scielo.br/pdf/rarv/v30n2/a05v30n2.pdf

ALVES, E.U.; SADER, R.; BRUNO, R.L.A.; ALVES, A.U. Maturação fisiológica de sementes de sabiá. Revista Brasileira de Sementes, v.27, n.1, p.1-8, 2005. http://www.scielo.br/pdf/rbs/v27n1/25175.pdf

BORGES, I.F.; GIUDICE, J.D.; BILIA, D.A.C.; FIGUEIREDORIBEIRO, R.C.L.; BARBEDO, C.J. Maturation of seeds of Caesalpinia echinata Lam. (Brazilwood), an endangered leguminous tree from the Brazilian Atlantic Forest. Brazilian Archives of Biology and Technology, v.48, n.6, p.851-861, 2005. http://www.scielo.br/pdf/babt/v48n6/27430.pdf

BRAGA, R. Plantas do Nordeste - Especialmente do Ceará. 4. ed, Natal: Editora Universitária da UFRN, 1960.

BRASIL. Ministério da Agricultura, Pecuária e Abastecimento. Regras para análise de sementes. Ministério da Agricultura, Pecuária e Abastecimento. Secretaria de Defesa Agropecuária. Brasília: MAPA/ACS, 2009. 395p. http://www.agricultura.gov.br/arq_editor/file/Laborat $\% \mathrm{C} 3 \% \mathrm{~B} 3$ rio/ Sementes/Regras\%20para\%20Analise\%20de\%20Sementes.pdf

CARVALHO, M.N.; NAKAGAWA, J. Sementes: ciência, tecnologia e produção. 4.ed. Jaboticabal: FUNEP, 2000. 588p.

CARVALHO, M.L.M.; NERY, M.C.; OLIVEIRA, L.M.; HILHORST, H.W.M.; GUIMARÃES, R.M. Morphophysiological development of Tabebuia serratifolia Vahl Nich. seeds. Scientia Agricola, v.65, n.6, p.643-651, 2008. http://www.scielo.br/pdf/sa/v65n6/12.pdf

CARVALHO, N.M. A secagem de sementes. São Paulo: FUNEP, 2005. 165p.

CORVELLO, W.B.V.; VILLELA, F.A.; NEDEL, J.L.; PESKE, S.T. Maturação fisiológica de sementes de cedro (Cedrela fissilis Vell.). Revista Brasileira de Sementes, v.21, n.2, p.23-27, 1999. http://www. abrates.org.br/revista/artigos/1999/v21n2/artigo04.pdf

CRUZ, E.D.; MARTINS, F.O.; CARVALHO, J.E.U. Biometria de frutos e sementes e germinação de jatobá-curuba (Hymenaea intermedia Ducke, Leguminosae - Caesalpinioideae). Revista Brasileira de Botânica, v.24, n.2, p.161-165, 2001. http://www.scielo.br/pdf/rbb/v24n2/a05v24n2.pdff

DAN, E.L.; MELLO, V.D.C.; WETZEL, C.T; POPINIGIS, F.; ZONTA, E.P. Transferência de matéria seca como método de avaliação do vigor de sementes de soja. Revista Brasileira de Sementes, v.9, n.3, p.45-55, 1987. http://www.abrates.org.br/revista/artigos/1987/v9n3/artigo05.pdff

DE-CARVALHO, P.S.; MIRANDA, S.C.; SANTOS, M.L. Germinação e dados biométricos de Hymenaea stigonocarpa Mart. ex Hayne (Leguminosae - Caesalpinoideae) - jatobá-do-cerrado. Revista A nhangüera, v.6 n.1, p.101-116, 2005.

FONSECA, F.L.; MENEGARIO, C.; MORI, E.S.; NAKAGAWA, J. Maturidade fisiológica das sementes do ipê amarelo Tabebuia chrysotricha (Mart. Ex DC.) Standl. Scientia Forestalis, n.69, p.36-141, 2005. http://www.ipef.br/publicacoes/scientia/nr69/cap12.pdf

GEMAQUE, R.C.R.; DAVIDE, A.C.; FARIA, J.M.R. Indicadores de maturidade fisiológica de sementes de ipê-roxo (Tabebuia impetiginosa (Mart.) Standl.). Cerne, v.8, n.2, p.84-91, 2002. http://www.dcf.ufla.br/ cerne/artigos/13-02-20095827v8_n2_artigo\%2007.pdf

IOSSI, E.; SADER, R.: MORO, F.V.; BARBOSA, J.C. Maturação fisiológica de sementes de Phoenix roebelenii O’Brien. Revista Brasileira de Sementes, v.29, n.1, p.147-154, 2007. http://www.scielo.br/pdf/rbs/ v29n1/20.pdf

LEONHARDT, C.; TILLMANN, M.A.A.; VILLELA, F.A. MATTEI, V.L. Maturação fisiológica de sementes de tarumã-de-espinho (Citharexylum montevidense) (Spreng.) Moldenke - Verbenaceae, no jardim Botânico de Porto Alegre, RS. Revista Brasileira de Sementes, v.23, n.1, p.100-107, 2001. http://www.abrates.org.br/revista/artigos/2001/v23n1/artigo14.pdf

LOPES, J.C.; DIAS, P.C.; PEREIRA, M.D. Maturação fisiológica de sementes de quaresmeira. Pesquisa Agropecuária Brasileira, v.40, n.8, p.811-816, 2005. http://www.scielo.br/pdf/pab/v40n8/a12v40n8.pdf

LOPES, J.C.; SOARES, A.S. Maturity of Miconia cinnamomifolia (DC.) Naud seed red oak. Ciência Agrotecnologia, v.30, n.4, p.623-628, 2006. http://www.scielo.br/scielo.php?pid=S1413$70542006000400005 \&$ script $=$ sci_arttext

MAGUIRE, J.D. Speed of germination: aid in selection and evaluation for seedling emergence and vigour. Crop Science, v.2, n.2, p.176-177, 1962.

MARCOS FILHO, J. Fisiologia de sementes de plantas cultivadas. Piracicaba: FEALQ, 2005. 495p.

MONTEIRO, J.M.; LINS NETO, E.M.F.; AMORIM, E.L.C.; STRATTMANN, R.R.; ARAUJO, E.L.; ALBUQUERQUE, V.P. Teor de taninos em três espécies medicinais arbóreas simpátricas da caatinga. Revista Árvore, v.29, n.6, p.999-1005, 2005. http://redalyc.uaemex.mx/ pdf/488/48829620.pdf

NAKAGAWA, J.; CAVARIANI, C.; ZUCARELI, C. Maturação, formas 
de secagem e qualidade fisiológica de sementes de mucuna-preta. Revista Brasileira de Sementes, v.27, n. 1, p.45-53, 2005. http://www.scielo.br/ pdf/rbs/v27n1/25180.pdf

NAKAGAWA, J.; ZUCARELI, C.; CAVARIANI, C.; GASPAROLIVEIRA, C. Maturação de sementes de mucuna-preta. Bioscience Journal, v.23, n.1, p.41-47, 2007. http://www.seer.ufu.br/index.php/ biosciencejournal/article/view/6381/4119

PESSOA, R.C.; MATSUMOTO, S.N.; MORAIS, O.M.; VALE, R.S.; LIMA, J.M. Germinação e maturidade fisiológica de sementes de Piptadenia viridiflora (Kunth.) Benth relacionadas a estádios de frutificação e conservação pós-colheita. Revista Árvore, v.34, n.4, p.617-625, 2010. http://www.scielo.br/scielo.php?pid=S0100$67622010000400006 \&$ script $=$ sci_arttext
SILVA, L.B.; SANTOS, F.A.R.; GASSON, P.; CUTLER, D. Anatomia e densidade básica da madeira de Caesalpinia pyramidalis Tul. (Fabaceae), espécie endêmica da caatinga do Nordeste do Brasil. Acta Botânica Brasílica, v.23, n.2, p.436-445, 2009. http://www.scielo.br/pdf/ abb/v23n2/v23n2a15.pdf

SILVA, L.M.M.; AGUIAR, I.B.; MATOS, V.P.; VIÉGAS, R.A.; MENDONÇA, I.F.C. Physiological maturity of Cnidosculus quercifolius Pax \& K. Hoffm. seeds. Scientia Forestalis, n.77, p.15-20, 2008. http:// www.ipef.br/publicacoes/scientia/nr77/cap02.pdf 